\title{
К ВОПРОСУ О ПРАВОВОМ РЕГУЛИРОВАНИИ ИСПОЛЬЗОВАНИЯ ЭЛЕКТРОННЫХ СИГАРЕТ
}

\begin{abstract}
ON THE LEGAL REGULATION
OF THE USE OF ELECTRONIC CIGARETTES
N. Geyt

Summary. Responding to public consensus about the habitual harmful tobacco smoking, including strategic views on the regulation of electronic cigarettes, suggests that they can crowd out conventional tobacco smoking from society, or vice versa. The initial position is supported by the expert community, which is confirmed by recent independent studies of two authoritative expert institutions at once - the British Health Agency and the Moscow School of Management Skolkovo. Their data shows that electronic cigarettes are an alternative to regular tobacco. In contrast to the parties, it is forbidden to take measures to make it clear that citizens of a country do not have voting rights in parliament and executive bodies. Because of state regulatory policy at the level of statistics.
\end{abstract}

Keywords: regulation, cigarettes, electronic cigarettes, turnover, differentiated approach.

\author{
Гейт Наталья Алексеевна \\ К.ф.н., дочент, Российская академия \\ государственной службы при Президенте РФ (г. Москва) \\ na.geyt@igsu.ru
}

Аннотация. Реагируя на общественный консенсус относительно вреда обычного табакокурения, государство до сих пор не выработало стратегический взгляд на регулирование электронных сигарет - считать ли их способом вытеснить из общества обычное табакокурение или, наоборот, рассматривать как скрытую форму подталкивания человека к курению табака. Первую позицию поддерживает экспертное сообщество, что подтверждается недавними независимыми исследованиями сразу двух авторитетных экспертных институтов - Британского агентства здравоохранения и Московской школы управления «Сколково». Их данные однозначно показывают, что электронные сигареты вытесняют из обихода обычный табак, создавая ему социально одобряемую и менее вредную для здоровья альтернативу. Им противостоят сторонники запретительных мер, позиция которых благосклонно воспринимается в парламенте и органах исполнительной власти в силу ее простоты, доступности запретительных мер для понимания обывателем и общего тренда нормотворчества на расширение области регулирования личного пространства гражданина. В результате регуляторная политика государства на уровне статистики показывает, что нуждается в изменении вектора.

Ключевые слова: регулирование, сигареты, электронные сигареты, оборот, дифференцированный подход.

дает в разряд угроз самому существованию наций с высоким уровнем курения среди населения и государств, которые эти нации образуют.

К таким государствам относится и Россия - в стране, по данным экспертов федерального проекта «Трезвая Россия», свыше 44 млн. курильщиков. Ежегодно в России умирают более 300 тыс. человек от причин, связанных с курением, что более чем в три раза превышает смертность от внешних причин смерти (дорожно-транспортное происшествие, отравление алкоголем, убийства вместе взятые).

С медицинской точки зрения курение является четвертым наиболее опасным фактором риска, для населения Российской Федерации, вызывающим 15,1\% смертельных исходов. По данным Росстата, в 2018 году от болезней системы кровообращения умерли более 770 тыс. россиян; при этом риск заболеваний сердца у курильщиков в 2.2 раза выше, чем у некурящих или у пользователей электронных сигарет, а риск атеросклероза 
у курильщиков выше в 6.5 раз. Таким образом, если бы удалось исключить фактор табакокурения, только сокращение заболевших сердечно-сосудистыми заболеваниями спасло бы от 250 тысяч до 450 тысяч человек в год - одно это позволило бы преодолеть рекордную естественную убыль населения в 259,6 тыс. жителей, зафиксированную Росстатом в январе-октябре прошлого года [14].

Массовое распространение курения табака в его классических формах - не только социально-демографический, но и экономический фактор. На круглом столе, прошедшем в Государственной Думе в конце февраля, прозвучала цифра - ежегодные потери экономики РФ от курения составляют почти 2,5 триллиона рублей, или 2,4\% ВВП. Система здравоохранения расходует на курильщиков до 1,1 трлн. рублей в год, что на 28,8\% выше расходов на некурящих [12].

Если исключить этот фактор, то расходы на здравоохранение сократятся на 7,9\% в год. Утвержденный Госдумой в декабре 2019 года закон предусматривает выделение из федерального бюджета в 2020 году на нужды здравоохранения более 996,1 млрд. руб. Таким образом, экономия могла бы составить около 78,7 млрд. руб. при полном отказе россиян от курения. С учетом расходов на здравоохранение региональных бюджетов общая сумма экономии могла быть и более масштабной [11].

22 ноября 2019 года правительство утвердило антитабачную концепцию Министерства здравоохранения Российской Федерации до 2035 года, которая распространяется не только на сигареты, но также и на вейпы, и системы нагревания табака. Концепция предусматривает снижение числа курильщиков среди взрослого населения к 2035 году до 21\%. Минздрав России совместно с заинтересованными федеральными органами исполнительной власти в течение шести месяцев должен разработать план реализации концепции и внести его в правительство.

При этом в концепции министерство по сути признает, что сегодняшние подходы, носящие почти исключительно запретительный и ограничивающий характер, не эффективны. В тексте концепции Министерства здравоохранения Российской Федерации изменил прогноз насчет числа курильщиков в России к 2035 году. В концепции по борьбе с курением раньше фигурировал показатель 5\% курящих, а в последней версии - 21\%. Сейчас доля любителей табака почти такая же - 22,5\%. То есть сегодняшний запретительный тренд даже по оценкам Минздрава, в самом лучшем случае, способен удержать ситуацию на нынешнем уровне - но никак не изменить ее в пользу отказа от традиционного курения.
Отсутствие достаточного, обоснованного регуляторного механизма давно вызывало озабоченность специалистов. Но вот в том, каким должен быть законодательный механизм такого регулирования - смешивающим в единое целое обычное табакокурение и современные электронные системы, или дифференцированным для обычных и электронных сигарет в зависимости от объективной оценки влияния на общественное здоровье вот в этом позиции экспертов расходятся по противоположным углам ринга.

И в центре этой крайне острой экспертной дискуссии - вопросы того, как регулировать оборот электронных систем; по отношению к традиционным формам курения табака, как уже упоминалось, фактически сложился консенсус.

При этом массовое движение населения от традиционного табакокурения в пользу электронных сигарет для России стал уже случившимся фактом - существует ли у этого процесса качественное законодательное сопровождение или нет.

По данным «Платформы ОФД», которая проанализировала 900 тыс. касс по всей России, снижение спроса на сигареты составило 5\%. При этом, по данным платформы «Такском» после анализа 17 млрд. кассовых чеков, спрос на сигареты и вовсе упал на 7\%.

Но аптечные инструменты отказа от курения здесь ни при чем - в аптеках падает спрос на препараты против никотиновой зависимости. Как сообщили в DSM Group, с начала 2019 года аптеки реализовали 3,1млн. соответствующих препаратов и товаров, что на 200 тыс. единиц меньше, чем за аналогичный период 2018 года [9].

Пользователи в массовом порядке переходят на вейпы и стики как альтернативу обычному табакокурению. В противовес традиционным табачным изделиям набирают популярность стики систем нагревания табака, продажи которых, по данным «Такском», с января по октябрь 2019 года взлетели в 4,5 раза в годовом исчислении. И все это - на фоне отсутствия цивилизованной регуляторной модели [9].

«Отсутствие правового регулирования употребления и продажи ЭСДН создает благодатную почву для бесконтрольного их использования, при этом не только несовершеннолетними, но и малолетними <...> что может оказать отрицательное воздействие на здоровье молодежи, нации в целом» - отмечалось в майском докладе федерального проекта «Трезвая Россия» [13]. С необходимостью продуманного, стабильного и разумного регулирования полностью согласны и представители от- 
расли - дикий рынок без берегов и правил вреден для бизнеса, подрывает репутацию качественных брендов и систем электронных сигарет, провоцирует необоснованные страхи и мифы среди аудитории.

Об этом - о ложных страхах и мифах - говорит, в частности, доклад, подготовленный Королевским колледжем Лондона по заказу британского агентства здравоохранения Public Health England (PHE).

«Ложные страхи» в отношении вейпинга удерживают курильщиков от использования электронных сигарет. ... Более половины курильщиков в Великобритании В настоящее время ошибочно полагают, что никотиносодержащие «вейпы» или электронные сигареты столь же опасны, как табачные изделия, и эти «ложные страхи» мешают курильщикам «переключиться» [с табака]» — говорится в докладе [5].

При этом ученые из Королевского колледжа Лондона заявили, что ошибочное мнение, что электронные сигареты более вредны, чем курение, быстро завоевало популярность после непроверенной - и оказавшейся в последствии недостоверной - информации о тысяч зарегистрированных случаев повреждения легких в Соединенных Штатах. в конце 2019 г. [3]

Напомним, что в августе прошлого года вейперы начали поступать с серьезными повреждениями легких в отделения неотложной помощи по всей территории США. Не было сразу понятно, что стояло за этой вспышкой, которая привела к 68 смертельным случаям в течение последующих месяцев [4].

Пресса немедленно связала эти заболевания с фактом потребления вейпов. Голос ученых, исследование которых было опубликовано в самом авторитетно мировом медицинском издании «Ланцет», указывающих, что наиболее вероятной причиной могла быть быть «грязная» поставка нелегальных продуктов из конопли (каннабис/марихуана), которую курили кустарным образом с использованием легальных электронных систем, услышан прессой не был - газетчики уже сделали заранее свой вывод [7]. Реагируя на поднявшуюся в масс-медиа волну паники, регуляторы во всем мире начали выводить с рынка никотиносодержащие продукты для вейпинга, в то время как табачные изделия оставались доступными, удерживая курильщиков от отказа от курения. Когда в итоге власти США все же определили, что «основной причиной» вспышки лёгочных заболеваний стало (гашишное масло (ацетат витамина Е), маховик популистских решений уже покатился по всему миру [6].

Отчет, шестой по счёту, опубликованный Public Health England на тему электронных сигарет, вероятно, ещё больше усилил разногласия о том, как регулировать электронные сигареты и подтвердил, что дело давно вышло за рутину нормотворческой работы - в этой теме столкнулись рациональные аргументы и информационные мифы [10].

Исследование Центра развития здравоохранения Московской школы управления «Сколково», в отличие от доклада специалистов Королевского колледжа Лондона по заказу британского агентства здравоохранения Public Health England (PHE), по понятным причинам больше относилось к социальным и экономическим, чем к медицинским аспектам темы.

Здесь уже упоминалось, что исключение фактора курения позволило бы сократить расходы на здравоохранение на 7,9\% в год, или на 78,7 млрд. руб. Исследователи «Сколково» выяснили, что переход курильщиков с обычного табакокурения на электронные сигареты, разумеется, не может перекрыть этот число теоретический показатель, но очень близок к нему по показателю эффективности. Экономия могла бы составить 6,4\% в год, или порядка 63,75 млрд. руб. при переходе курильщиков на ЭСДН. А учитывая рост популярности электронных систем у бывших «обычных» курильщиков на 450\% в год (!) - эта цифра не кажется уж слишком теоретической. Разумеется, при грамотном, правильном регулировании оборота этих систем.

Каким же должно быть это регулирование? Специалисты «Сколково» провели интервью с ключевыми фигурами, которые представляют государственные структуры и научные институты, часть из которых приглашены в качестве членов Экспертного совета по борьбе с курением в Сколково.

С точки зрения опрошенных специалистов, главное в регуляторном механизме - проводить различие между подходом к регулированию сигарет и ЭСДН: для сигарет необходимо сохранение ограничений на курение в общественных местах, рекламу и т.д., а для ЭСДН сделать акцент не на запреты, а на стимулирование переключения на их потребление «обычных» курильщиков. Следует отметить, что это некоторый новый взгляд: до исследования Московской школы управления «Сколково» все говорили о разной степени жесткости ограничений, накладываемых на ЭСДН, но никто не рассматривал вопросы стимулирования перехода к электронным системам «обычных» курильщиков. Позиция специалистов, обобщенная в исследовании, показывает, что эта тема уже возникла и активно обсуждается в среде тех, кто принимает решения.

В этом контексте совсем иначе звучит другое предложение со стороны опрошенных специалистов и руково- 
Таблица 1. Сценарии реализации антитабачной стратегии

\begin{tabular}{|l|l|l|l|l|}
\hline К 2035 & Концепция М3 & Сценарий 1 & Сценарий 2 & Сценарий 3 \\
\hline $\begin{array}{l}\text { DALY, вызванные курением (годы } \\
\text { жизни, СКорректированные } \\
\text { по нетрудоспособности) }\end{array}$ & 3887918 & 3288156 & 2197791 & 2422410 \\
\hline PYLL (потерянные годы жизни) & 2332751 & 1972893 & 1098895 & 1212205 \\
\hline Количество курильщиков & 23443600 & 18632492 & 9335398 & 9907953 \\
\hline Количество вейперов & - & 5331474 & 19997733 & 15642392 \\
\hline $\begin{array}{l}\text { Стомость курения и вейпинга для } \\
\text { системы здравоохранения (млрд. руб./ } \\
\text { год) }\end{array}$ & 158,7 & 135,1 & 96,6 & 93,2 \\
\hline
\end{tabular}

Источник: составлено авторами.

Таблица 2. Демографический эффект от реализации антитабачной стратегии

\begin{tabular}{|l|l|l|l|l|}
\hline К 2035 & Концепция М3 & Сценарий 1 & Сценарий 2 & Сценарий 3 \\
\hline $\begin{array}{l}\text { Среднее ежегодное количество } \\
\text { новорожденных }\end{array}$ & - & 625750 & 628435 & 628618 \\
\hline
\end{tabular}

Источник: составлено авторами.

дителей: начать работу с врачами. Врачи должны стать лидерами мнений, чтобы давать курильщикам рекомендации. В первую очередь, в таком обучении должны быть привлечены те медики, которые связаны с репродуктивной сферой.

Третье интегрированное предложение - введение обязательной сертификации компонентов жидкостей для ЭСДН. В целом, как подчеркнули интервьюируемые, наибольших успехов добиваются страны, которые применяют дифференцированный подход к регулированию ЭСДН и курению «традиционных» сигарет - Франция, Великобритания, Новая Зеландия, Канада.

Другая часть доклада опиралось на кабинетное исследование, подготовленное специалистами Московской школы управления «Сколково»на базе данных Росстата, ВЦИОМа и других источников. В центре исследования - наиболее распространенная в медицинской среде гипотеза, в которой риски для здоровья, связанные с вейпингом, консервативно оцениваются на $80 \%$ ниже, чем риски, связанные с курением [8].

Специалисты «Сколково» рассматривали следующие сценарии [8]:

1. сценарий 1 предусматривал реализацию стратегии с существенными ограничениями рынка ЭСДН;

2. сценарий 2 - выдвигал ЭСДН как основное средство снижения потребления никотина, с необхо- димыми ограничениями (прежде всего, по доступу несовершеннолетних).

3. сценарий 3 носил промежуточный характер реализация стратегии с разумным регулированием ЭСДН: 18+ ограничение по продажам возрастом 18+, демонстрация продукции в точках продажи и направленная на взрослых курильщиков, реклама в местах с контролем по возрасту, выделенные зоны для вейпинга в общественных местах, отдельные от зон для курения.

В докладе указано, что при реализации сценария жесткого регулирования количество «традиционных» курильщиков к 2035 году было бы вдвое больше, чем при реализации сценария стимулирования перехода на ЭСДН - 18632492 человека к 9335 398. Так же вдвое выше распространенность курения среди взрослого населения - 16\% при «жестком» сценарии и $8 \%$ при стимулирующем переход. При этом общее число пользователей - как электронных систем, так и курильщиков «традиционных» форм - было выше во втором сценарии [8].

В итоге специалисты Московской школы управления «Сколково» пришли к выводу, что оптимальным было бы реализовать сценарий сочетания подходов антитабачной стратегии с мерами разумного, достаточного регулирования.

Именно этот вариант позволяет достичь минимальных суммарных значений «традиционных» курильщиков 
и пользователей электронных систем при наивысших значениях медицинской эффективности.

Сценарий 3 также даёт наибольший демографический эффект (табл. 2)

Резюмируя, отметим, что несмотря на рассмотрение проблемных вопросов научного осмысления антитабачной стратегии и наличия значительного количества рациональных аргументов, негативные «мифы» в данной сфере, особенно распространяющиеся с помощью средств массовой информации, довлеют не только над российским, но и над зарубежным законодателем. В связи с этим при реализации антитабачной стратегии и совершенствовании правового регулирования оборота электронных сигарет необходимо учитывать социально-экономический и демографический эффекты от внедряемых правовых механизмов.

\section{ЛИТЕРАТУРА}

1. Бессонов Д.В., Алексеев С. Г., Барбин Н. М. Вейпинг — вопросы безопасности // Безопасность жизнедеятельности. 2017. № 10 (202). С. 10-16.

2. Будылева К.Е., Слепцов В.А. 0 некоторых проблемах охраны здоровья граждан от воздействия табачного дыма // Молодой ученый. 2019. C. $160-162$.

3. Бурбело Б.Ю., Анчаков С. А. Запрет курения табака и потребления алкогольной продукции в общественных местах: вопросы административно-юрисдикционной деятельности полиции // Вестник Луганской академии внутренних дел имени Э. А. Дидоренко. 2019. № 2 (7). С. 96-106.

4. Галибин А. Н. Уголовная ответственность за контрабанду алкогольной продукции и табачных изделий // Modern Science. 2019. № 6-2. С. 140-142.

5. Глушков Е.Л. К вопросу противодействия преступлениям, связанным с реализацией некоторых товаров, не отвечающих требованиям безопасности жизни и здоровья потребителей // Вестник Белгородского юридического института МВД России имени И. Д. Путилина. 2018. № 4. С. 43-49.

6. Голубова Т.Н., Махкамова 3. Р., Рубанова А. Р. Обзор международного опыта по борьбе с табакокурением // Таврический медико-биологический вестник. 2017. T. 20. № 1. С. 123-130.

7. Женщины и мужчины России. Отчет Росстата [Электронный ресурс] // URL: https://www.gks.ru/free_doc/doc_2018/wo-man18.pdf (дата 0бращения 12.04.2020).

8. Исследование московской школы управления «Сколково» [Электронный ресурс] // URL: https://tass.ru/obschestvo/7550207 (дата 0бращения 17.03.2020).

9. Исследование рынка электронных сигарет [Электронный ресурc] // URL: https://marketing.rbc.ru/research/32635/ (дата 0бращения 14.04.2020).

10. Липатова Н.Г., Кожуханов Н. М. Особенности взимания акциза на ввозимую табачную продукцию // Вестник Российской таможенной академии. 2017. № 2. C. 131-136.

11. Олофинская Т.У., Шелестюков В. Н., Шлее И. П. Правовое регулирование вопросов, связанных с профилактикой преступлений в сфере незаконного оборота наркотических средств // Проблемы экономики и юридической практики. 2017. № 2. С. 175-180.

12. Сенин В.Б., Сальников А. В. Проблемы взаимодействия бизнеса и власти в сфере коммуникаций на примере ограничения публикации рекламных сообщений табачной продукции // Бизнес. Общество. Власть. 2017. № 26. С. 88-98.

13. Федеральный проект «Трезвая Россия» [Электронный ресурc] // URL: http://www.trezvros.ru (дата обращения 16.04.2020).

14. Федеральный отчет Росстата. Женщины и мужчины России [Электронный ресурс] // URL: https://www.gks.ru/free_doc/doc_2018/wo-man18.pdf (дата 06ращения 12.04.2020). 